\title{
Variable X-linked recessive hypopituitarism with evidence of gonadotropin deficiency in two pre-pubertal males
}

\author{
W. B. Zipf, R. P. Kelch and G. E. BACON \\ C. S. Mott Childrens Hospital, Department of Pediatrics and Communicable Diseases, \\ University of Michigan, Ann Arbor, Michigan, U.S.A.
}

\begin{abstract}
Two half-brothers with short stature secondary to growth hormone deficiency and a family history implicating X-linked transmission were studied extensively for other endocrine abnormalities. The proband had a normal physical examination, except for small stature and small external genitalia. ACTH and TSH release were normal. LH and FSH responses during an i.v. GnRH test were severely blunted. His half-brother also had a normal physical examination, except for severe short stature and very small external genitalia. Deficiencies of ACTH, and TSH as well as GH were documented. An i.v. GnRH test showed no LH or FSH response. These studies support the existence of an $X$-linked recessive form of hypopituitarism and portend the clinical usefulness of the i.v. GnRH test in evaluating gonadotropin reserve.
\end{abstract}

Received 3 May, revised 1 November, accepted for publication 10 November 1976

Inherited hypopituitarism is an uncommon but well-documented condition (Rimoin et al. 1966, McKusick 1971). Until recently, only an autosomal recessive pattern of inheritance could be demonstrated convincingly. In 1971, two separate reports suggested an X-linked recessive pattern of inheritance (Phelen et al. 1971, Schimke et al. 1971). This report of two cases of multiple, but variable, deficiencies of anterior pituitary hormones further suggests the $\mathrm{X}$ linked mode of inheritance and illustrates the probable usefulness of the gonadotropinreleasing hormone $(\mathrm{GnRH})$ test in the diag- nosis of gonadotropin deficiency in prepubertal children.

\section{Case Reports}

Case 1, D.H. (UMMC 1-183-460), was born on January 26,1965 to a 34-year-old white female after an uncomplicated full-term pregnancy (Fig. 1). His birth weight was $4.5 \mathrm{~kg}$; his length was not available. He was seen initially at the University of Michigan Medical Center for evaluation of short stature at $5 \frac{1}{2}$ years. Physical examination revealed a short, pudgy, white male with small

This work was supported in part by Program Project HD08333, the National Foundation, and USPHS 5P11GM15559. 
Table 1

Serum $\mathrm{LH}$ and FSH responses to i.v. synthetic $\mathrm{GnRH}$

\begin{tabular}{|c|c|c|c|c|c|c|}
\hline Subjects & $\begin{array}{c}\text { Age } \\
\text { (years) }\end{array}$ & $\begin{array}{c}\text { Dose } \\
(1 \mathrm{~g} / \mathrm{kg})\end{array}$ & $\begin{array}{c}\text { Maximum LH } \\
\text { increment } \\
(\mathrm{mlU} / \mathrm{ml})\end{array}$ & $\begin{array}{c}\text { LH response } \\
\text { area } 120 \mathrm{~min} \\
(\mathrm{~m} / \mathrm{U}-\mathrm{min})\end{array}$ & $\begin{array}{l}\text { Maximum } \\
\text { FSH increment } \\
(\mathrm{m} / \mathrm{U} / \mathrm{ml})\end{array}$ & $\begin{array}{l}\text { FSH response } \\
\text { area } 120 \mathrm{~min} \\
(\mathrm{mlU}-\mathrm{min})\end{array}$ \\
\hline \multirow[t]{3}{*}{ D.H. } & 9. $1 / 12$ & " $\mathrm{g} / \mathrm{m}^{2}$ & 0 & $0 \dagger$ & 2.2 & 149.0 \\
\hline & $10-2 / 12$ & $10 \quad: \mathrm{g} / \mathrm{m}^{2}$ & 3.3 & $56.9 \dagger$ & 2.3 & 78.7 \\
\hline & $10-3 / 12$ & $2.5 \mathrm{lg} / \mathrm{kg}$ & 2.0 & 28.3 & 2.4 & 140.5 \\
\hline P.H. & 6 & $2.5 \mathrm{\prime g} / \mathrm{kg}$ & 2.1 & $36.5 \dagger$ & 0 & o† \\
\hline $\begin{array}{l}\text { R.H. } \\
\text { Controls" }\end{array}$ & $11-10 / 12$ & $2.5 \mathrm{ng} / \mathrm{kg}$ & 4.0 & 232.0 & 4.1 & 281.8 \\
\hline$(n=4)$ & & $10 \quad \| \mathrm{g} / \mathrm{m}^{2}$ & $\begin{array}{c}8.0 \pm 2 \\
(4-14)\end{array}$ & $\begin{array}{c}390 \pm 105 \\
(185-623)\end{array}$ & $\begin{array}{c}5.0 \pm 0.5 \\
(3-6)\end{array}$ & $\begin{array}{c}195 \pm 54 \\
(99-349)\end{array}$ \\
\hline$(n=10)$ & & $2.5 \mathrm{rg} / \mathrm{kg}$ & $\begin{array}{l}8.4 \pm 1.3 \\
(3.9-18.8)\end{array}$ & $\begin{array}{l}567 \pm 105 \\
(330-1359)\end{array}$ & $\begin{array}{l}9.3 \pm 1.7 \\
(1.9-18.8)\end{array}$ & $\begin{array}{l}715 \pm 125 \\
(211-1410)\end{array}$ \\
\hline
\end{tabular}

- Mean \pm s.e. mean ()$=$ range for short normal prepubertal males with bone ages less than 10 years.

t Non-significant response.

external genitalia; the length of the stretched phallus was $2.5 \mathrm{~cm}(-4 \mathrm{s.d})$. His height was $87 \mathrm{~cm}(-5 \mathrm{s.d}$.), weight $11.4 \mathrm{~kg}(-3$ s.d.) and head circumference $49.5 \mathrm{~cm}(-2$ s.d.). Vital signs were normal. Significant laboratory studies included normal serum protein bound iodine $(5.1, \mathrm{~g} / \mathrm{dl})$, skull roentgenograms, and a skeletal age of 2 years. Fasting serum growth hormone $(\mathrm{GH})$ was less than $2 \mathrm{ng} / \mathrm{ml}$ after a 3 -day pretreatment with diethylstilbesterol (Bacon et al. 1969). An estrogen-primed arginine-insulin stimulation test (ATT/ITT) showed a maximum $\mathrm{GH}$ response of $3 \mathrm{ng} / \mathrm{ml}$.

At $7+\frac{1}{12}$ years of age, he was admitted to

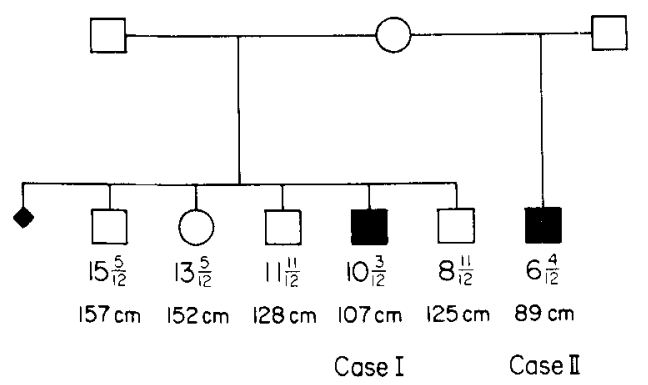

Fig. 1. Family pedigree, illustrating $X$-linked transmission. Case 1, D.H. : Case 2, P.H. the C. S. Mott Children's Hospital for further evaluation. A repeat estrogen-primed ATT/ITT demonstrated a maximum GH response of $5.8 \mathrm{ng} / \mathrm{ml}$. Serum thyroxine iodine was $5.4 \mu \mathrm{g} / \mathrm{dl}$ (nl 2.9-6.4). Urinary 17-hydroxycorticosteroids were $1.9 \mathrm{mg} / \mathrm{m}^{2 /}$ 24 hours ( $\mathrm{nl} \overline{\mathrm{x}}=3.1 \mathrm{mg} / \mathrm{m}^{2} / 24$ hours). Eight-hour deoxycorticoid response to i.v. metyrapone test was $9 \mu \mathrm{g} / \mathrm{dl}(\mathrm{nl}>6 \mu \mathrm{g} / \mathrm{dl})$ (Bacon et al. 1975). Subsequently, luteinizing hormone (LH) and follicle stimulating hormone (FSH) responsiveness to i.v. synthetic GnRH (Parke, Davis) was abnormally low on three occasions (Table 1). Treatment with human growth hormone, 2 IU i.m. three times jer week was begun at $9 \frac{1}{12}$ years.* Pretreatment growth velocity was $3.5 \mathrm{~cm}$ per year. During the first 12 months of GH therapy, D.H. grew $7.0 \mathrm{~cm}$ despite poor compliance.

Case 2.P.H., the half brother of D.H., was born on December 19, 1968, after an uncomplicated full-term pregnancy (Fig. 1).

\footnotetext{
* Haman growth hormone was supplied by the National Pituitary Agency of the University of Maryland and the NIAMDD.
} 


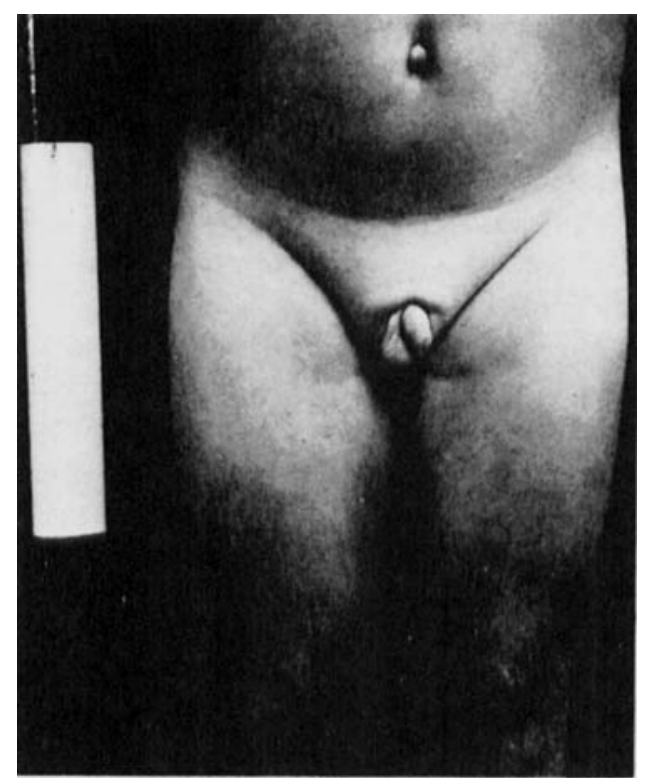

Fig. 2. Photograph of P.H. (Case 2) illustrating small external genitalia (segments of reference bar equal to 6 inches).

His birth weight was $3.8 \mathrm{~kg}$; his length was not available. A circumcision was deferred because of his small penile size.

P.H. was first seen at the University of Michigan Medical Center at age $3 \frac{11}{12}$ years. Physical examination revealed a short, pudgy, immature-appearing white male with a high pitched voice. His height was 79.5 $\mathrm{cm}(-7$ s.d.), weight $11.0 \mathrm{~kg}(-2$ s.d.) and head circumference $48.3 \mathrm{~cm}$ ( -2 s.d.). Vital signs were normal. Examination of the external genitalia revealed a small penis, 1.5 $\mathrm{cm}$ in length (-6.5 s.d.) (Fig. 2). The left testicle was palpable in the inguinal canal. The right testicle was $1.0 \mathrm{~cm}$ in length.

Laboratory studies revealed a skeletal age of 18 months, serum thyroxine iodine of $2.1 \mu \mathrm{g} / \mathrm{dl}$, low urinary 17-hydroxycorticosteroids $\left(0.7 \mathrm{mg} / \mathrm{m}^{2 / 24}\right.$ hours $)$ and serum thyroid stimulating hormone of $9 \mu \mathrm{U} / \mathrm{ml}$. P.H. was begun on 1 grain desiccated thyroid U.S.P. daily (p.o.) and $2.5 \mathrm{mg}$ hydro- cortisone b.i.d. (p.o.). During the next 2 years he grew $6.8 \mathrm{~cm}$ and gained $500 \mathrm{~g}$. At $5 \frac{5}{12}$ years an estrogen-primed ATT/ITT was performed; maximum growth hormone response was $0.3 \mathrm{ng} / \mathrm{ml}$. There was no increase in serum cortisol concentration during the insulin tolerance test. During an i.v. metyrapone test there was no detectable rise in serum deoxycorticoids. At 6 years of age, he failed to demonstrate a significant gonadotropin response during an i.v. GnRH (Table 1). P.H. was begun on GH therapy at 6 years, and after 8 months of intermittent therapy ( 2 IU i.m. 3 times per week, 2 out of every 3 months), he grew $5.1 \mathrm{~cm}$.

The family history (Fig. 1) revealed that the biologic fathers of D.H. and P.H. were different; this paternal difference was confirmed by detailed blood typing. The maternal family history was traced for six generations with no evidence of consanguinity or short stature, and the family history of the father of P.H. was also negative for short stature. The father of D.H. could not be located.

An $11 \frac{11}{12}$-year-old full brother of D.H. was also evaluated (Fig. 1). This child (R.H.) was $128 \mathrm{~cm}$ tall $(-2.5$ s.d.), and he had surgically corrected cryptorchidism on the right. He had a delayed bone age (6 $6 \frac{1}{2}$ years), a normal serum growth hormone concentration of $5.6 \mathrm{ng} / \mathrm{ml}(\mathrm{nl}>5.0 \mathrm{ng} / \mathrm{ml})$ after estrogen priming and exercise (Keenan et al. 1972), and low normal FSH and LH responses to GnRH stimulation. A peak growth hormone level of $7.0 \mathrm{ng} / \mathrm{ml}$ was also obtained during the GnRH test.

Three other siblings were found to be normal in height and weight. The mother was $157.5 \mathrm{~cm}$ tall and in good health. After an estrogen-primed exercise stimulation test her serum growth hormone rose to 8.6 $\mathrm{ng} / \mathrm{ml}$. The mother was $\mathrm{XgA}$ negative and no other $\mathrm{X}$-chromosome markers could be identified. 


\section{Materials and Methods}

Growth hormone, FSH and LH concentrations were determined by established double antibody radioimmunoassay techniques (Kelch et al. 1975). GnRH stimulation tests were carried out in the Upjohn Center for Clinical Pharmacology, and were interpreted as previously described (Kelch et al. 1975). An LH response was considered significant when five of the six samples between +8 and +45 min were greater than 3 standard deviations above the mean of the five pre-infusion samples. An FSH response was considered significant when four of the five samples between +20 and +90 minutes were greater than 2 standard deviations above the mean of the control samples. $\mathrm{XgA}$ and detailed blood typing for confirmation of parentage were performed through the courtesy of Dr. Henry Gershowitz of the Department of Human Genetics at the University of Michigan.

\section{Discussion}

The family pedigree is consistent with an $\mathrm{X}$-linked recessive trait, but there is some variability in its expression. Case 1 (D.H.) presented with many of the typical features of a growth hormone deficient child, with the additional physical findings of small external genitalia. Anterior pituitary testing demonstrated probable gonadotropin deficiency as well as GH deficiency.

Case 2 (P.H.) presented with many of the classical findings of growth hormone deficiency, and extremely small external genitalia. He was deficient in TSH, ACTH, GH and most likely $\mathrm{LH}$ and FSH. Maintenance doses of thyroid hormone and cortisol did not increase his growth velocity.

One other sibling in this family (R.H.) also had significant short stature (Fig. 1). His bone age was delayed but he had a normal physical examination except for unilateral cryptorchidism, normal growth velocity, and normal serum thyroxine. Complete $\mathrm{GH}$ deficiency was ruled out by low normal $\mathrm{GH}$ responses to stimulation tests. LH and FSH responses to GnRH (Table 1) were significant, and the $\triangle \max$ values and response areas were at the lower limits of the normal range.

The occurrence of inherited forms of growth hormone deficiency has been well documented. Rimoin et al. (1968) reported an extensive review of the world's literature from which they were able to gather reports of 51 kindreds in which more than one individual had apparent growth hormone deficiency. Analysis of these families implicated an autosomal recessive form of inheritance as the most likely mode of genetic transmission in most instances. However, included in these and other reviews (Brasel et al. 1965) there are occasional family histories in which only male siblings are affected, suggesting an X-linked mode of inheritance. This possibility was given further support in 1971 when Schimke et al. (1971) and Phelen et al. (1971) reported unrelated kindreds that demonstrated family pedigrees strongly implicating an X-linked pattern of inheritance with variability in the expression of other hormonal deficiencies. McKusick (1971) has subsequently classified this Xlinked transmitted form of hypopituitarism as type IV.

The evaluation and subsequent classification of a child with evidence of one or more anterior pituitary hormone deficiencies is complicated by the fact that the complete manifestation of the condition may take years to develop (Goodman et al. 1968). The diagnosis of gonadotropin deficiency in the prepubertal individual must be made with caution in view of the known marked delay in onset of sexual maturation associated with GH deficiency (Rimoin \& Schimke 1971). A possible physical clue is the presence of small external genitalia 
which is known to occur in hypopituitary infants (Goodman et al. 1968, Rimoin \& Schimke 1971, Feldman \& Smith 1975). Men with isolated gonadotropin deficiency also have small external genitalia and, sometimes, a history of micropenis during infancy and childhood (Laron \& Karishanski 1975). These observations would be consistent with the concept that fetal male genital growth after 12 weeks of gestation is dependent on the presence of fetal gonadotropins (Feldman \& Smith 1975). The possibility that the absence of fetal growth hormone during gestation may produce a similar result has also been suggested (Laron \& Sarel 1970).

The early diagnosis of gonadotropin deficiency would be beneficial for optimal management of these children. The possibility that a synthetic GnRH test might be useful in predicting gonadotropin deficiency in the prepubertal individual has been suggested previously (Grumbach et al. 1974, Kelch et al. 1976). We have recently studied $\mathrm{LH}$ and FSH responses to i.v. synthetic GnRH in prepubertal males with isolated GH deficiency and multiple pituitary deficiencies (including known or probable gonadotropin deficiency) and compared them to the responses of short normal prepubertal males. Our data revealed significantly lower responses in most of the patients with suspected isolated GH deficiency, and severely blunted or absent responses in the patients with multiple pituitary deficiencies. In this group of patients, replacement therapy with GH did not significantly increase the responsiveness to GnRH (Kelch et al, 1976).

In D.H., the presence of small external genitalia, the two nonsignificant LH responses, and the single significant but very blunted LH response suggest either complete or partial gonadotropin deficiency. The very blunted FSH responses would support this latter possibility. P. H. did not respond to GnRH, has multiple pituitary hor- mone deficiencies and very small external genitalia. The likelihood of his being gonadotropin deficient is great. R.H. demonstrated low normal responses for both GH and gonadotropins and, even though our impression is that he is normal, the possibility of a partial expression of $\mathrm{X}$-linked recessive hypopituitarism cannot be excluded.

In the two previous reports of $\mathrm{X}$-linked recessive hypopituitarism, the mothers of the affected individuals were of normal height. The mother of the two affected children in this report showed no signs of an endocrine abnormality. This would suggest that the heterozygous state in the female does not result in any detectable abnormality. An easily identifiable X-chromosome genetic marker that would allow us to follow the carrier state, such as XgA heterozygosity or color blindness, was not present in this instance. However, attempts at identifying such markers would be of interest and beneficial for genetic counseling.

\section{Acknowledgment}

We gratefully acknowledge the assistance of $\mathrm{R}$. Prieskorn and the clerical staff of the Upjohn Center for Clinical Pharmacology, the expert technical assistance of M. Markovs, J. Huss, and the secretarial assistance of I. Paluch and C. Mooney.

\section{References}

Bacon, G. E., R. M. Larson, M. L. Spencer \& R. P. Kelch (1975). Intravenous metyrapone testing. Amer. J. Dis. Child. 129, 1042-1044.

Bacon, G. E., G. H. Lowrey \& M. Knoller (1969). Comparison of arginine infusion and diethylstilbesterol as a means of provoking growth hormone secretion. J. Pediat. 75, 385-390.

Brasel, J. A., J. C. Wright, L. Wilkins \& R. M. Blizzard (1965). An evaluation of seventyfive patients with hypopituitarism beginning in childhood. Amer. J. Med. 38, 484-498. 
Feldman, K. W. \& D. W. Smith (1975). Fetal phallic growth and penile standards for newborn male infants. J. Pediat. 86, 395-398.

Goodman, H. G., M. M. Grumbach \& S. L. Kaplan (1968). Growth and growth hormone. II. A comparison of isolated growth hormone deficiency and multiple pituitary-hormone deficiencies in 35 patients with idiopathic hypopituitary dwarfism. N.E.J.M. 278 , $57-68$.

Grumbach, M. M., J. C. Roth, S. L. Kaplan \& R. P. Kelch (1974). Hypothalamic-pituitary regulation in man: Evidence and concepts derived from clinical research, Control of the Onset of Puberty, ed. Grumbach, M. M., G. D. Grave \& F. E. Mayer. New York, John Wiley \& Sons, Inc., p. 148.

Keenan, B. S., L. B. Killmer Jr. \& J. Sode (1972). Growth hormone response to exercise: A test of pituitary function in children. Pediatrics 50, 760-764.

Kelch, R. P., L. E. Clemens, M. Markovs, M. H. Westhoff \& D. Hawkins (1975). Metabolism and effects of synthetic gonadotropinreleasing hormone $(\mathrm{GnRH})$ in children and adults: J. clin. Endocr. (Kbh.) 40, 53-61.

Kelch, R. P., M. Markovs \& J. Huss (1976). LH and FSH responsiveness to intravenous gonadotropin-releasing hormone (GnRH) in children with hypothalamic or pituitary disorders: Lack of effect of replacement therapy with human growth hormone. J. clin. Endocr. (Kbh.) 42, 1104-1113.

Laron, Z, \& A. Karishanski (1975). Penile size and growth in children and adolescents with isolated gonadotropin deficiency. Pediat. Res. 9, 671 .

Laron, Z. \& R. Sarel (1970). Penis and testi- cular size in patients with growth hormone deficiency. Acta endocr. (Kbh.) 63, 629633.

McKusick, V. A. (1971). Mendelian Inheritance in Man, 3rd Ed. Baltimore, The Johns Hopkins Press, pp. 490 \& 593.

Phelen, P. D., J. Connelly, F. I. R. Martin \& H. N. B. Wettenhall (1971). X-linked recessive hypopituitarism. Birth Defects: Original Article Series, Vol. VII, No. 6, 24-27.

Rimoin, D. L., T. J. Merimee, D. Rabinowitz \& J. A. McKusick (1968). Genetic aspects of clinical endocrinology. Recent Progr. Horm. Res. 24, 365-437.

Rimoin, D. L., T. J. Merimee \& V. A. Mc Kusick (1966). Growth hormone deficiency in man: Isolated recessively inherited defect. Science 152, 1635-1637.

Rimoin, D. L. \& R. N. Schimke (1971). Anterior pituitary. Genetic Disorders on the Endocrine Glands. St. Louis, C. V. Mosby Co., p. 36.

Schimke, R. N., J. J. Spaulding \& J. G. Hollowell (1971). X-linked congenital panhypopituitarism. Birth Defects: Original Article Series, Vol. VII, No. 6, 21-23.

\section{Address:}

W. B. Zipf, M.D.

Birth Defects Diagnostic Program

C. S. Mott Childrens Hospital

Room $F 2428$

Department of Pediatrics \& Communicable Diseases

University of Michigan

Ann Arbor, Michigan 48109

U.S.A. 